\title{
Human Extinction from a Thomist Perspective
}

\begin{abstract}
"Existential risks" are risks that threaten the destruction of humanity's long-term potential: risks of nuclear wars, pandemics, supervolcano eruptions, and so on. On standard utilitarianism, it seems, the reduction of such risks should be a key global priority today. Many effective altruists agree with this verdict. But how should the importance of these risks be assessed on a Christian moral theory? In this paper, I begin to answer this question - taking Thomas Aquinas as a reference, and the risks of anthropogenic extinction as an example. I'll suggest that on a Thomist framework, driving ourselves extinct would constitute a complete failure to fulfil our God-given nature, a radical form of hubris, and a loss of cosmological significance. So the reduction of such risks seems vital for Thomists, or Christians more broadly. Indeed, I end with the thought that these considerations are not parochially Christian, or indeed specifically religious: everyone with a similar view of mankind - as immensely valuable yet fallen and fragile - should agree that existential risks are a pressing moral concern.
\end{abstract}

\section{Introduction}

Let us say that "humanity's long-term potential" is the set of all possible desirable futures that are open to us. ${ }^{1}$ This potential is enormous, and contains some fantastic scenarios. Consider

Flourishing: We survive for another billion years, and on average there are always 10 billion people, who live very good 100 -year-long lives. So there are 100 million billion future people with very good lives.

This scenario is possible. The earth seems to remain sustainably inhabitable by at least 10 billion people, ${ }^{2}$ and for another 1.75 billion years. ${ }^{3}$ The quality of our lives seems to have increased continuously, ${ }^{4}$ and it seems possible for this trend to continue. So we might have a glorious future ahead of us.

However, we might also founder. Let us say that an "existential catastrophe" is the destruction of humanity's long-term potential, and that an "existential risk" (or "x-risk") is a risk that threatens this destruction. There

1 This definition of "humanity's long-term potential", as well as the following definitions of "existential catastrophes" and "existential risks", are very slightly adapted versions of the definitions in Ord, The Precipice, ch. 2.

2 United Nations, "World Population Monitoring," 30.

3 Rushby et al., "Habitable Zone."

4 See e.g. the data collected in Pinker, Enlightenment Now. 
are various ways for our potential to be destroyed, even in the course of our century. Extreme climate events might engender a civilisational collapse, say, as a consequence of which humanity gets permanently reduced in numbers and locked into a cultural and technological state resembling that of the Middle Ages. But the most straightforward such catastrophe would be

Extinction: We die out this century.

This scenario is also possible. Indeed, Extinction may be more likely than most of us think. There are many possibly lethal x-risks: nuclear wars, developments in biotechnology or artificial intelligence, climate change, pandemics, supervolcanos, asteroids, and so on. ${ }^{5}$ In an informal poll, risk experts reckoned that there is a $19 \%$ probability that we will die out this century. ${ }^{6}$ The Stern Review on the Economics of Climate Change assumed a $9.5 \%$ likelihood of our dying out in the next 100 years. ${ }^{7}$ And a recent report by the Global Challenges Foundation suggests that climate change, nuclear war and artificial intelligence alone might ultimately result in extinction with a probability of between $5 \%$ and $10 \% .^{8}$

Importantly, whether Flourishing or Extinction will materialise partly depends on us. Indeed, it may depend on what we do today. We could now promote academic research on x-risks, ${ }^{9}$ global political measures for peace, sustainability or AI safety, ${ }^{10}$ the development of asteroid defence systems, ${ }^{11}$ shelters, ${ }^{12}$ risk-proof food technologies, ${ }^{13}$ and so on. And while none of these measures will bring x-risks down to zero, they will arguably at least reduce them. So all of this raises a very real, practical question. How important is it, morally speaking, that we now take measures to make Flourishing more likely?

5 See e.g. Bostrom and Ćirković, Global Catastrophic Risks.

6 Sandberg and Bostrom, "Catastrophic Risks Survey."

7 HM Treasury, "Stern Review."

8 Pamlin and Armstrong, "Global Challenges." More precisely, the report distinguishes between "infinite impact", "where civilisation collapses to a state of great suffering and does not recover, or a situation where all human life ends", and an "infinite impact threshold", "an impact that can trigger a chain of events that could result first in a civilisation collapse, and then later result in an infinite impact" ("Global Challenges," 40). The above numbers are their estimates for infinite impact thresholds.

9 Bostrom and Ćirković, Global Catastrophic Risks.

10 Cave and ÓhÉigeartaigh, "Bridging."

11 Bucknam and Gold, "Asteroid Threat?"

12 Hanson, "Catastrophe."

13 Denkenberger and Pearce, Feeding Everyone. 
The answer depends on the correct moral theory. It is most straightforward on standard hedonistic total utilitarianism. Suppose we increase the probability of Flourishing over Extinction by just 1 millionth of a percentage point. In terms of overall expected welfare (setting non-human sentience aside), this is equivalent to saving about 1 billion lives, with certainty. So according to utilitarianism, even such tiny increases in probability are astronomically important. Indeed, Nick Bostrom suggested that x-risk reduction "has such high utility that standard utilitarians ought to focus all their efforts on it." 14 But this implication is not restricted to utilitarianism. Something very similar will emerge on any view that assigns weight to expected impartial welfare increases. Consider effective altruism (EA). EA is the project of using evidence and reasoning to determine how we can do the most good and taking action on this basis. ${ }^{15}$ This does not presuppose any specific moral theory about what the good is, or about what other reasons we have beyond doing the most good. But effective altruists typically give considerable weight to impartial expected welfare considerations. And as long as we do, the utilitarian rationale will loom large. Thus according to a 2018 survey, EA-leaders consider measures targeted at the far future (e.g. x-risk reduction) 33 times more effective than measures targeted at poverty reduction. ${ }^{16}$ The EA organisation 80,000 hours suggests that "if you want to help people in general, your key concern shouldn't be to help the present generation, but to ensure that the future goes well in the long-term." ${ }^{17}$ And many effective altruists already donate their money towards $\mathrm{x}$-risk reduction rather than, say, short term animal welfare improvements.

In this paper, I will ask how the importance of x-risk reduction should be assessed on a Christian moral theory. My main claim will be that Christian morality largely agrees with EA that x-risk reduction is extremely important - albeit for different reasons. So Christians should emphatically support the above-mentioned measures to increase the probability of Flourishing.

Let me clarify. First, there is no such thing as the Christian moral doctrine. One of the philosophically most elaborate and historically most influential developments of Christian thought is the work of Thomas Aquinas. So I will take this as my starting point and argue first and foremost that core Thomist assumptions support x-risk reduction. Thomas's specific inter-

14 Bostrom, "Astronomical Waste," 308ff.; see also Parfit, Reasons, 452f.; Beckstead, Far Future; and Bostrom, "Existential Risk."

15 See MacAskill, Doing Good Better.

16 Wiblin and Lempel, "New survey."

17 Todd, "Long-term value." 
pretations of these assumptions are often unappealing today. But I will also claim that they can be interpreted more plausibly, that their core idea is still authoritative for many Christians, and that on any plausible interpretation they ground an argument for x-risk reduction. So while I will start with Thomas, my conclusions should appeal to quite many contemporary Christians. Indeed, I will ultimately indicate that these assumptions need not even be interpreted in a specifically Christian manner but emerge in some form or other from a number of worldviews (cf. section 4). Second, there are different $\mathrm{x}$-risk scenarios, and they raise different moral issues. I think the argument is clearest for a class of cases I will call "non-transitionary anthropogenic extinction": ways in which humanity might literally die out (hence "extinction"), as a direct consequence of our own actions (or "anthropogenic"), and without being superseded by non-human intelligence (thus "non-transitionary"). So it is on these cases that I will focus. It would be interesting to explore other scenarios in which we are replaced by another form of intelligence, non-extinction x-risks (which our above definition includes) like an extended stage of suffering, or scenarios of natural extinction like volcano eruptions. My arguments will have upshots for such cases too. But I will not explore them here. Third, there are different ways in which, or different agents for whom, reducing extinction risks might be important. In what follows, I will mostly be considering a collective perspective. That is, I will assume that we as humanity collectively do certain things. And I will focus on whether we ought to do anything to mitigate the relevant risks - rather than on whether you individually ought to. The existence of this collective perspective might be controversial. But I think it is plausible. ${ }^{18}$ Christian moral theory, or at least Thomas, also seems to assume it (cf. section 2.1). And many important issues emerge only or more clearly from it. So I will assume it in what follows.

In short, my question is about how important it is, on roughly Thomist premises, for us to reduce risks of non-transitionary anthropogenic extinction. I will first present three considerations to the effect that, if we did drive ourselves extinct, this would be morally very problematic - a hubristic failure in perfection with cosmologically bad effects (section 2). I will then discuss some countervailing considerations, suggesting that even though such extinction would be bad, we needn't take measures against it - because God will not let it happen, or because we would not intend it, or because at any rate, it is not imminent (section 3). I will argue that none of these

18 See e.g. Dietz, "Collective Obligations." 
latter considerations cut any ice. So I will conclude that on roughly Thomist premises it's extremely important for us to reduce such risks.

\section{Three Thomist Considerations}

There are many Thomist considerations that would bear on risks of nontransitionary anthropogenic extinction. For instance, in driving ourselves extinct, we would presumably kill the last representatives of humanity. On a Thomist perspective, those killings will be morally problematic simply as killings. ${ }^{19}$ Yet this has nothing to do with the fact that those killings lead to extinction. So let us see whether there would be anything distinctly problematic about extinction, if we brought it about. There is.

\subsection{The Natural Law}

A first consideration follows from Thomas's teleology, or from the Aristotelian strand in his thinking. Recall that for Thomas, the order of the cosmos is teleological. This teleology is grounded in the fact that the cosmos is subject to God. And it takes the form of a law for us: "the universe is governed by Divine Reason. Wherefore the very Idea of the government of things in God [...] has the nature of a law." 20 For Thomas, following this "eternal law" - or Divine "will" 21 or "plan" 22 for all things - is the ethical imperative for us. So what does it command? We cannot know God's intent "in itself", 23 at least not in this earthly life. ${ }^{24}$ But we can know it "in its effect", through its manifestations in creation, or through the "natural law" that we recognise as structuring the physical universe. In particular, we can detect God's plan for us through the natural inclinations He has implanted in us: "all things partake somewhat of the eternal law[:] [...] from its being imprinted on them, they derive their respective inclinations to their proper acts and ends." 25 In other words, our inclinations allow an indirect cognition of the essence of God's will, quite like sunrays allow an indirect cognition of the substance of the sun. ${ }^{26}$ So what are our natural

19 See ST, ii-II, q64.

20 ST, i-II, q91 a1, co.

21 ST, i-II, q93 a4, ad1.

22 ST, i-II, q93 a3, co.

23 ST, i-II, q93 a2, co.

24 See ibid; ST, I, q12 a11.

25 ST, i-II, q91 a2, co.

26 ST, i-II, q93 a2, co. 
inclinations? Thomas speaks of three kinds: "in man there is first of all an inclination [...] which he has in common with all substances: [...] the preservation of its own being [...]. Secondly, there is in man an inclination [...] which he has in common with other animals: [...] sexual intercourse, education of offspring and so forth. Thirdly, there is in man an inclination to good, according to the nature of his reason [...]: [...] to know the truth about God." 27 What is crucial for present purposes is the second type of inclination. Procreation or the "preservation of the species" is firmly part of our "natural good" 28 or of what the natural law commands us to do.

Now Thomas does not believe that everyone must follow all of these inclinations, or that everyone must have offspring. It is permissible for some to remain celibate. ${ }^{29}$ But we as a collective have a duty - a "duty [...] to be fulfilled by the multitude" 30 - to procreate. This grounds a straightforward consideration for reducing extinction risks. By going extinct, we would fail to attain our end or to accord with the natural law. Indeed, our failure would be profound. It would not just be some of us flouting this law the bad apples in an overall virtuous whole. We would fail collectively, as an entire species, to attain our end. And (at least as far as this life is concerned) we would not just fail in one aspect of perfection, while still able to excel in others. Our survival is a precondition for any aspect of our flourishing. So our extinction would mean we fail comprehensively, in all respects of our end. And of course we would not just temporarily fall short of our calling. Once we have gone extinct, there is no second bite at the apple. It would mean we have foundered irreversibly. So the moral failure in anthropogenic extinction would seem complete. In short:

Natural law: We ought to attain our natural end. Our extinction would prevent us from doing so - collectively, comprehensively, and irreversibly. Thus non-transitionary anthropogenic extinction would amount to a total moral failure of us as a species.

This is a first consideration for why our extinction would be problematic.

Now I suppose that this kind of rationale is not parochially Thomist, but should appeal to Christians quite broadly. Thomas himself interprets the natural law pertaining to procreation very radically - e.g. as permitting a

27 ST, i-II, q94 a2, co.

28 SCG, III, 122-9.

29 See e.g. ST, ii-II, q152.

30 ST, ii-II, q152 a2, ad1. 
non-procreative life only for the sake of the "contemplation of truth", ${ }^{31}$ and as prohibiting any intercourse known to be non-reproductive. ${ }^{32}$ This would mean that our procreation-related obligations go much beyond preventing extinction. And it would mean that contemporary liberal moral thought is radically wrong about the good human life, and about intercourse among people of the same sex, or people who for whatever reasons cannot or do not want to reproduce. Many contemporary Christians will want to resist these implications. But we need not understand the general idea of a "natural law" in this manner. Plausibly, other aspects of the human end (athletic, social, emotional) are just as important as "the contemplation of truth." So there are good lives without children beyond those of philosophers and priests. ${ }^{33}$ Also, perhaps there are other functions of human sexuality (e.g. bonding), such that non-reproductive intercourse is not a misuse of sexual organs. After all, there is plenty of non-reproductive sexuality among non-human animals. ${ }^{34}$ The details of the natural law are a matter of large debate. ${ }^{35}$ But I presume that the general idea of a "natural law" is still quite prominent for Christians today. Indeed, assuming the universe manifests God's intentions, it is a very natural assumption. And I suppose that on any plausible interpretation, it will ground a consideration against anthropogenic extinction: whatever it implies about childfree individuals, contraception or homosexuality, it seems hard to square the natural law with an heirless self-eradication of our species. If the law commands anything, it seems, it commands us (with Gen 1:28) to "be fruitful and multiply." 36 So a consideration along these lines should be authoritative to

31 ST, ii-II, q152 a2, co; also ST, ii-II, q153 a2, co. Thomas doesn't say this explicitly in these passages. He says that the goods of the body are subordinate or "directed" to the goods of the soul, and that virginity (or a lack of bodily good) is justified if done for the sake of Divine contemplation (or good of the soul; ST, ii-II, q152 a2, co). I'm reading the conditional here as a biconditional.

32 SCG, III, 122; also ST, ii-II, q153 a2, co.

33 See e.g. Nussbaum, "Non-Relative Virtues," or Creating Capabilities.

34 See e.g. Bagemihl, Biological Exuberance.

35 For a classic systematic exploration of natural law, see Finnis, Natural Law. For an in-depth treatment of Aquinas's theory, see e.g. - among very many others - Lisska, Aquinas's Theory.

36 Historically, this broad rationale has not appealed to all Christians, of course. Paul himself suggests it would be best if everyone was celibate (see 1 Cor. 7:7: "I wish that all of you were as I am"). And the Cathars even thought reproduction was a moral evil. I thank Felix Timmermann and Christoph Halbig for pointing this out to me. 
Christians quite broadly. Self-inflicted extinction would constitute a total failure in our executing our designated role. ${ }^{37}$

\subsection{Humility}

However, there is more to anthropogenic extinction than a failure to reproduce. Let us look at the precise way in which, through anthropogenic extinction, we would fail to attain our end. According to Thomas, there are different ways to fall short of perfection. One is through utter passivity, or sloth, or a "sorrow" that "so oppresses man as to draw him away entirely from good deeds." 38 Thus we might just not bother to do anything much at all, and therefore fail in perfection. Another way of failing lies in falling too low, or being overcome with "the lower appetite, namely the concupiscible." 39 So we might behave like lower animals, and fail to live up to our standards. But drawing on Augustine, Thomas says that "the most grievous of sins" 40 consists in aiming too high - in failing to respect our limitations or acting as if we were God. To do so is to commit the sin of pride, hubris, or superbia. Following Augustine, ${ }^{41}$ Thomas characterises a prideful man as someone who "aims higher than he is", or does not "tend to that which is proportionate to him." ${ }^{2} 2$ And what is proportionate to us is of course not so by coincidence, but due to Divine assignment. Thus pride is opposed specifically to humility: "humility properly regards the subjection of man to God [...]. Hence pride properly regards lack of this subjection, in so far as a man raises himself above that which is appointed to him according to the Divine rule." 43 And in this sense, as far as the "aversion from the immutable good" 44 is concerned, pride is the most grievous sin: it is not just a failure

37 Note that on a common understanding of the natural law, it does not unconditionally command you to strive for survival. On the contrary, it is natural for your life to end at some point, and it can be wrong for you to take means of prolonging it beyond e.g., enhancement or certain life-sustaining treatments. But this does not jeopardise the above argument. Species do not seem to have an inherent natural endpoint. Species as a whole do not age. Moreover, I am only concerned with anthropogenic extinction. And it seems implausible that guarding ourselves against that - e.g., promoting measures for peace, sustainability or AI safety - would somehow be unnatural.

38 ST, ii-II, q35 a2, co.

39 ST, ii-II, q153 a5, co.

40 ST, ii-II, q162 a6, co.

41 De Civ. Dei, XIV, 13.

42 ST, ii-II, q162 a1, co.

43 ST, ii-II, q162 a5, co.

44 ST, ii-II, q162 a6, co. 
through ignorance or weakness or an innocent desire for another good, but an active "withstanding" or "resisting" or manifesting "contempt of" God. 45

What does this imply in practice? Thomas specifies what he means. Pride is not any old undue desire. It is, specifically, an "appetite for excellence in excess of right reason" - or an inordinate imitation of the powers or competences of God. ${ }^{46}$ This may take various forms. We may be pridefully curious about things we cannot know, such as facts about good and evil. ${ }^{47} \mathrm{Or}$ we may unduly discard our need for Divine grace, deeming ourselves capable of happiness on our own. ${ }^{48}$ But a more specific power that is not appointed to us is decisions about life and death: "it belongs to God alone to pronounce sentence of death and life." ${ }^{9} 9$ Thus to kill someone, or - I take it - actively prevent them from coming into existence, is generally to show an appetite for a power that does not pertain to us. And if all of this is true, then non-transitionary anthropogenic extinction, in particular, would manifest an enormous form of pride. Note that on most such scenarios, we would fall prey to technologies we were unable to control - nuclear weapons, artificial intelligence, biotechnology, or whatever. So our extinction would mean that we had overestimated our mastery over these fabrications, and the invulnerability we could leverage in the face of them. It would mean we were prideful in the general sense of desiring an undue excellence. And the upshot of this would be, specifically, a life-death decision on an astronomical scale: preventing lives perhaps by the quadrillions. It would mean we were prideful in this more specific sense too. Or in short:

Humility: Non-transitionary anthropogenic extinction would mean we overstrained our power as a species. And the upshot of it would be a life-death decision on an astronomical scale. Thus it would amount to an enormous form of superbia.

This is a second consideration for why our extinction would be problematic.

And here too, I suppose this consideration should appeal to Christians quite broadly. Again, Thomas's specific interpretation of God's authority over life/death-decisions should be controversial. He suggests that, while permitting us to execute death penalty, ${ }^{50}$ this authority absolutely prohibits

45 Ibid.

46 ST, ii-II, q162 a1, ad2; emphasis added.

47 ST, ii-II, q163 a1, ad3.

48 ST, ii-II, q163 a2, co.

49 ST, ii-II, q64 a5, co.

50 ST, ii-II, q64 a2, co. 
suicide, ${ }^{51}$ and prohibits abortion from the moment of ensoulment ${ }^{52}-$ which some people have claimed, according to Thomas's metaphysical principles and the known facts about embryology, takes place at the moment of fertilisation. ${ }^{53}$ This would mean self-extinction can under no circumstances be permissible. And it would mean that contemporary liberal moral thought is radically wrong about the death penalty, abortion, or suicide and euthanasia. Many contemporary Christians will want to resist these implications. But again, we need not interpret the general idea of superbia in this manner. After all, it is implausible that criminals are "dangerous and infectious to the community" and must be cut away like an infected part of a body. ${ }^{54}$ Perhaps suicide can in some instances of extreme pain, or loss of autonomy or dignity, be a manifestation of self-love. And if so, perhaps we can then view ourselves as authorised by God - or His commandment to love ourselves ${ }^{55}$ - to end our lives. After all, Thomas himself (defending Abraham's intention to kill Isaac) suggests that "he who at God's command kills an innocent man does not sin." 56 Perhaps some forms of abortion (e.g. after rape) can also be seen as an expression of self-love or -respect. Or perhaps we must ascribe to Aquinas a different view of ensoulment, ${ }^{57}$ or simply reject some of his metaphysics in light of more recent discoveries. Again, the details of superbia are contested. 58 But I assume that the pertinent general idea is still prominent among Christians today. Indeed, that playing God is a sin is a natural corollary of theism.

51 ST, ii-II, q64 a5, co.

52 See e.g. ST, I, q118f.

53 Haldane and Lee, "Aquinas on Human Ensoulment," 273. In the Scriptum super Sententiis, following Aristotle, Thomas himself suggests that the soul is infused after 40 days for men and after 90 days for women (SSS III, d3 q5 a2, co).

54 ST, ii-II, q64 a2, co.

55 See e.g. Mat 22:39.

56 ST, ii-II, q64 a6, ad1.

57 Pasnau, Thomas Aquinas.

58 There is a lot of recent literature concerning Thomas on humility. For longer treatments, see e.g. Tadie, Between Humilities, or Fullam, The Virtue of Humility. As far as I see, Thomas himself does not discuss whether birth control (or "contraception") infringes on God's dominion over life/death-decisions. But the Catholic church has since leveraged this argument. Yet perhaps a ban on contraception need not follow from humility either. Perhaps Thomists may appeal to the doctrine of double effect, and compare well-intentioned prevention of fertilisation with well-intentioned killing in self-defence (cf. section 3.2). Or perhaps they might again claim to be authorised in this decision by the commandment to love ourselves, and love our partners, and our (potential) children for whom we could not be sufficiently responsible parents. 
The in-principle-ban on life/death-decisions has a very firm grounding in the Bible. ${ }^{59}$ And I suppose that on any plausible interpretation, these ideas ground a consideration against anthropogenic extinction: whatever they imply about the death penalty, abortion, and suicide, the dictates of humility seem hardly compatible with our developing a technology that accidentally seals the fate of our whole species. So again, this consideration should have import for Christians quite broadly. Self-inflicted extinction would constitute a shattering form of superbia.

\subsection{The Value of Humanity}

But we need to see another aspect of Thomas's view of humanity too, which is perhaps most distinctly biblical, and which is implicit in the third kind of inclination he ascribes us. Without doubt, we are not God. But we are nonetheless made to know the truth about Him. In fact, of all corporeal things (i.e., disregarding angels), we are the only ones whose nature enables such knowledge. And this, for Thomas, marks our "dignity". It is this dignity which made it fitting for Jesus to adopt human nature, rather than becoming an animal or any other thing: "in the irrational creature the fitness of dignity is wanting." ${ }^{60}$ Indeed, it is these intellectual capacities that ground our likeness to God - a likeness greater than that of any non-rational creature, ${ }^{61}$ and sufficient to say we are His "image": "intellectual creatures alone [...] are made to God's image." ${ }^{2}$ And it is this which ultimately manifests that God loves us more than any other thing. So Aquinas quotes Augustine approvingly: "God loves all things that He has made, and amongst them rational creatures more, and of these, especially those who are members of His only-begotten Son Himself." 63

In other words, and as Thomas says very explicitly, ${ }^{64}$ of all corporeal things we are the most valuable, or those with most "goodness". And this difference is categorical. So our extinction would have cosmological ramifications. For standard utilitarians, there is no categorical difference between a world populated by flourishing societies of people and a world populated by one lonely lizard basking in the sun and feeling a tinge of pleasure.

59 Thomas cites Deut. 32:39, for instance: "I put to death and I bring to life".

60 ST, III, q4 a1, co.

61 See ST, I, q93 a2, co.

62 Ibid.

63 ST, I, q20 a3, sc.

64 ST, I, q20 a4, co. 
The difference is a matter of degree. For Aquinas, that is different. In a world devoid of higher intelligence, there is nothing that is made to God's image - nothing with our special dignity or perfection. This would radically undercut the perfection of the universe, as God created it, which depends on the varieties of goodness. ${ }^{65}$ So our extinction would change the face of creation. Or in short:

The value of humanity: Non-transitionary anthropogenic extinction would constitute the destruction of the most valuable aspect of creation - and thus a loss of categorical cosmological significance.

That is a third consideration for why our extinction would be problematic.

Again, I suppose that this consideration should appeal to Christians very broadly. Thomas interprets the order of creation very radically. $\mathrm{He}$ suggests that everything else exists for $u s^{66}$ - such that we may use animals simply as means for our ends, say, and the self-interested killing of another person's ox wrongs at most its owner. ${ }^{67}$ This would mean that our extinction would literally destroy the purpose of the physical universe. And it would mean that much contemporary thought is radically wrong about animals, or other aspects of the natural world. Again, many Christians will want to resist these implications, or so I hope. But the distinct value of humans need not be interpreted this radically. Perhaps our "dominion" over animals (mentioned in Gen 1:26) does not mean we can use them simply as means. Perhaps it means we must use our de facto power in the manner of a loving and respectful guard. ${ }^{68}$ And similarly with every other aspect of creation - ecosystems, plants, and the climate. Again, the exact nature of our status is a large question. But the general idea of our special value still seems very prominent. It does seem hard to avoid if we take seriously that man is "God's image", or has a special (perhaps responsibility-implying) dominion over the earth - and very plausible on the assumption of God's human embodiment in Christ. And on any interpretation, our special status will ground a consideration against extinction: whatever it implies about our responsibilities towards animals, the face of creation will be changed categorically if we drive ourselves extinct. So this consideration should be authoritative to Christians very broadly. Self-inflicted extinction would constitute a destruction with cosmological import.

65 See e.g. ST, I, q47.

66 ST, ii-II, q64 a1, co.

67 Ibid.

68 See e.g. Linzey, Christianity, ch. 2. 
Plausibly, there are other Christian considerations that bear on x-risks, at least once we move beyond Thomas. Most notably, perhaps Christian caritas simply gives us reasons to increase expected impartial welfare. ${ }^{69}$ If it does, the EA rationale will be very pertinent to Christians as it stands. But whether that is an apt interpretation of the Christian virtue - or whether the latter is more about making people happy than about making happy people - will be controversial. And at any rate, I think these are the three most distinctly Christian concerns. So let me leave it at that for now.

\section{Discussion}

If all of this is right, non-transitionary anthropogenic extinction would be a morally highly problematic result. Such extinction would not just amount to a regrettable form of imprudence - but to a failure to fulfil our God-given role. It would not amount to any old failure of this kind - but to a prideful failure to achieve our end. And it would not just be an inconsequential overstepping of our dominion - but an unauthorised decision with categorical cosmological ramifications. ${ }^{70}$ But as mentioned, humanity can now (in the form of the present generation) take measures to reduce the likelihood that it will eventually bring this result about. So this suggests that we have very strong reasons to take some such measures. It suggests that Christians too have strong reasons to donate their money towards $\mathrm{x}$-risk reduction rather than, say, disaster relief; to conduct $\mathrm{x}$-risk research rather than enquiries about the cause of the grief of a neighbour; or to advocate political measures for long-term safety rather than for short-term caritative purposes. But let us not get ahead of ourselves. Some considerations in Thomas's philosophy seem to suggest that even if extinction would, as far as we know, be bad, it is not important that we now do much about it in practice. So let me turn to some of these theological and moral countervailing concerns. This will not simply corroborate the results so far. It will also help clarify the precise form and weight of what the above rationale implies.

69 See e.g. William Paley's utilitarian Christianity (Paley, Principles, esp. book II)

70 Perhaps it is worth noting that in principle, these considerations are logically independent. One might accept some but not all of them. For instance, one might doubt that our natural inclinations reveal a Divine law, but still accept the cosmological disvalue of human extinction. 


\subsection{Theological Considerations: Divine Providence}

One apparent reason against extinction risk activism is Divine providence. Again, for Thomas, everything is subject to God. And Thomas's God is all-knowing, all-powerful, and all-good: "In God there exists the most perfect knowledge", 71 "He can do all things that are possible absolutely [or do not imply a contradiction in terms]", 72 and He "loves all existing things." 73 One might conclude from this that God will not allow us to go extinct, or that if He does it is somehow just for the better. And from this one might infer that we need not do anything to prevent our extinction in practice. Reducing extinction risks is obviated by the rule of a loving God.

This is difficult and well-trodden terrain. But God's existence does not in general seem to warrant any heedlessness. Consider risks of road accidents, say. And suppose any accident accords with His will. It is an interesting question what precisely this implies. Perhaps it warrants a certain ultimate serenity or comfort: a reassurance at the thought that whatever happens on our roads has its mysterious rightness in the grand scheme of things. Perhaps it warrants a fundamental form of trust: a consolation in the belief that our diligence will be duly rewarded. ${ }^{74}$ Perhaps it means that while things are ultimately in God's hands, he wants to achieve His ends through us being virtuous and pious. ${ }^{75}$ But in any case, God's unfathomable values cannot act as a guide for us, or as an excuse to depart from the norms and expectations we are given. So Christian hope must be distinguished from optimism that accidents will not occur, or from feeling exonerated from the need to take caution. Christians ought to see to it that they stop at red lights, respect speed limits, and check their brakes - and just as carefully as everyone else. Indeed, Thomas is the first to emphasise that we are obligated to such circumspection. ${ }^{76}$ In short, Divine providence does not affect our

71 ST, I, q14 a1, co.

72 ST, I, q25 a3, co.

73 ST, I, q20 a2, co.

74 See ST, ii-II, q22 a1, co.

75 A passage from the book of Esther is sometimes interpreted along these lines. Mordecai seems to believe that the Jewish people will survive anyway, but that Esther should nonetheless try to avert the genocide: "For if you remain silent at this time, relief and deliverance for the Jews will arise from another place, but you and your father's family will perish" (Est. 4:14). I thank Dominic Roser for mentioning the above thought, and this passage, to me.

76 See e.g. ST, ii-II, q64 a8, co. 
need to reduce road risks in practice. But then it is unclear why it should do so with risks of human extinction. ${ }^{77}$

One might suggest that there is something special about human extinction, setting it apart from everyday hazards, and making it particularly unlikely. Perhaps it is precisely because we are His "image", or uniquely most valuable, that God will not allow us to perish. Perhaps Jesus's redemption of mankind would have been futile if some sorrowful two thousand years later He let us burn up or wither away. ${ }^{78}$ Or perhaps, more specifically, there is evidence in scripture that we will survive: the primal great flood precisely did not erase us, and after that deluge there seems to have been a promise of survival - that "never again will all life be destroyed by the waters of a flood" (Gen. 9:11). This is not the place to dive deep into Christian theology. But it is hard to see why such reasonings should give us much confidence. The Lord moves in mysterious ways. If all known misery is compatible with His providence, it must surely at least be possible that He would allow us to go extinct. In particular, there are many more passages in scripture painting a grim prospect of extinction than promising a boundless glorious future. And many such visions of the "end of time" indicate anthropogenic extermination - that "the nations in the four corners of the earth" are gathered for "battle" or "war" (Rev. 20:8), right before "the earth and the heavens" are gone (Rev. 20:11). If anything, according to the Bible, anthropogenic extinction seems a very live option. So Divine providence might have implications for the metaphysics and ultimate unfathomable significance of our doomsday. But it does not seem to warrant our heedlessness about extinction risks in practice. If the above considerations are sound, we, just like any generation in the future, must see to it that it is not us who bring a Johannine finale about.

77 In his contribution to this collection, Dominic Roser suggests that Christianity warrants a certain renunciation of control. He contradicts my claims here - and suggests, say, that Christians may reasonably check their brakes somewhat less often, or may take considerably less precautionary measures against $\mathrm{x}$-risks, than atheists do. This view seems to me, among other things, unstable. It seems that God's existence would either require standard full-blown caution (as I think Thomas suggests) or would warrant total relinquishment of it. It seems hard to see why He would warrant a certain but only a certain trust in the course of events. At any rate, I doubt that most Christians understand their faith in this manner. And even if Roser is right, any such limited trust in things would arguably still not undermine my practical conclusions.

78 I thank Felix Koch for mentioning this thought to me. 


\subsection{Moral Considerations: Deontology}

Let us look at moral considerations that might mitigate the importance of reducing extinction risks. One such consideration concerns intentions. For Thomas, the permissibility of our actions can depend on what we intend. More precisely, he held, or indeed introduced, the doctrine of double effect (or DDE). According to this doctrine, there is a difference between the effects we intend an action to have, and the effects we merely foresee but do not specifically intend. While it is always impermissible to intend evil effects, it can be permissible to cause them, if what you intend is good. For instance, you may kill in self-defence, if you intend to save your life and merely foresee the death of your aggressor. ${ }^{79}$ This bears on risks of extinction. Perhaps non-transitionary anthropogenic extinction would be a very bad result. But one might suggest that as long as we do not intend to effect it, we would not have acted impermissibly: an unintentional mass life-prevention is not prideful, and an unintentional thwarting of perfection or erasing of God's image is not morally wrong. So if our intentions are fine, we need not worry about reducing extinction risks. ${ }^{80}$

But this argument is a non-starter. It might well be worse to intend our extinction rather than to merely foresee it. For Thomas, it would mean that our action would lack "goodness from its end", and not just from its circumstances or species. ${ }^{81}$ But this does not mean that unintentional extinction would not be wrong, or even specifically prideful. There is no blanket permission for the well-intentioned. You must not speed through the cross-walk and put people at risk, even with the laudable aim of being punctual at the faculty meeting. Thomas says explicitly that you are "in a sense guilty of voluntary homicide" - and thus (I take it) of superbia - if you kill someone unintentionally but without having taken "due care." ${ }^{2} \mathrm{He}$ does not specify when precisely the DDE allows you to accept a foreseen evil. But he suggests it depends on (i) the expected goodness of the intended good, (ii) the expected badness of the foreseen evil - or on the "proportion" between the two 83 - and (iii) on whether the harmful action is "necessary" 84 for the good, or whether there are ways of securing the good without

79 See, ST, ii-II, q64 a7, co.

80 I thank Eric Sampson and Jonathan Erhardt for mentioning this thought to me.

81 ST, i-II, q18, esp. a7, co.

82 ST, ii-II, q64 a8, co.

83 ST, ii-II, q64 a7, co.

84 Ibid. 
these bad effects. These criteria decidedly command reducing extinction risks. Sure, many technologies that involve such risks also promise important goods. But if my arguments are right, the moral costs are potentially tremendous. And there are less risky courses of action which detract little from the expected good. The above-mentioned measures would reduce the relevant risks but would not really jeopardise the benefits these technologies promise. So it seems absolutely obligatory to take them. Going on as we do does seem like scorching through the cross-walk for timeliness at the meeting. That is not killing for the sake of the killing. But it is a serious violation of the negative constraint of the DDE. And thus it is surely grave enough. ${ }^{85}$

Let us consider another countervailing consideration. Perhaps extinction would be terrible. But for all we know, it is not actually imminent. Indeed, compared to more immediate moral callings like global poverty, gender justice, or disaster relief, it seems very remote. According to utilitarianism or EA, such distance does not matter. These views are relevantly impartial. But perhaps Christian morality is different. One might suggest Christian morality is more concerned with visible, immediate, near-at-hand moral problems - the wounded person alongside the road (Luk. 10:30), or perhaps the literal "neighbour" (Mrk. 12:31) - and does not warrant too much concern about such far-distant matters. In fact, Thomas himself is explicit that we should be partial, at least in the virtue of caritas: "Among our neighbours, we should love them more who are more closely connected to us." 86 So one might conclude that although our extinction would be bad, we need not worry about reducing the relevant risks - or at least not now, or not with resources we could direct towards these more immediate concerns.

85 Strictly speaking, perhaps extinction would not even be a "foreseen" effect of our actions. By "foreseen" [praecogitatus] Thomas seems to mean "known with certainty to result" (see, e.g. ST, i-II, q20 a5, co). But we are not certain that promoting artificial intelligence, say, will result in extinction. We are just not certain that it will not. In discussing the DDE, Thomas does not deal with uncertainty. But he does elsewhere. In ST, i-II, q20 a5, co, he says: "if the consequences [of an action] are not foreseen, we must make a distinction. Because if they follow from the nature of the action and in the majority of cases [...] the consequences increase the goodness or malice of that action [...]. On the other hand, if the consequences follow by accident and seldom, then they do not increase the goodness or malice of the action." This cannot be right. Throwing stones off a cliff might kill passersby below in only $5 \%$ of cases. But then it is nonetheless wrong. Thomas lacked the concept of expected value. Today, we would surely interpret the doctrine in terms of that concept, or some related one.

86 DQV, q2 a9, co; see also ST, ii-II, q31 a3, co. 
But this would be a mistake. Christian morality may be partialist about caritas. So there may be a tension between Christian benevolence and the impartialist EA-directive to do the most good. But on the considerations that I have sketched, reducing extinction risks is not a form of "doing good", or of charity, or of fulfilling any positive obligation. It is to ensure or make more likely - that we do not flout our end, overstep our dominion, or wreck the crown of creation. Formally, it is to ensure that we satisfy the constraint of the DDE. In other words, it is to respect a perfect negative duty. And Thomas does not seem to endorse partiality or discounting in such negative duties, and neither does Christian morality more broadly. On Christian morality, killing, say, is wrong. And doing what will kill someone in a month is presumably ceteris paribus just as wrong as doing what will kill someone in a year, or in a thousand years for that matter. So the sheer temporal distance of human extinction in itself does not seem to obviate such risk reduction. On the contrary, note that the negative character of this obligation has implications for how it may be weighed against others. For utilitarians, the obligation to reduce x-risks is formally on a par with (other) obligations of benevolence, such as obligations to support the poor. So it ought to be weighed against them. For Thomist Christians, if I am right, this is different. As a negative obligation, the obligation to reduce risks of extinction must not be weighed against positive imperfect obligations or cannot be discharged by doing enough by way of benevolence elsewhere. It is quite simply a perfect duty.

There is a final point worth noting. For utilitarians, notoriously, we may take any means for the sake of the good end. If killing an innocent scientist reduces x-risks, we presumably ought to kill them. For Thomist Christians this will be different. Thomas explicitly accepts deontological constraints: "some [actions] are evil, whatever their result may be." ${ }^{77}$ So Thomist Christians must not do everything to reduce such risks. They generally must not kill or lie or steal for that purpose. In practice, however, this will not make much of a difference. The most salient means of reducing the relevant risks include academic research, or global measures for peace, sustainability or AI safety. None of these measures seem to violate any constraints. So even if Christian morality is deontological in nature, there are plenty of good ways to start making Flourishing more likely.

87 ST, ii-II, q88 a2, ad2. 


\section{Conclusion}

If all of this is right, it is not just that non-transitionary anthropogenic extinction would, as far as we know, be a disastrous result - a cosmologically salient prideful failure to achieve our end. At least in practice, and as a matter of a negative constraint against lack of "due care" that in principle seems neither discountable nor weighable against positive obligations, Thomist Christians have very strong reasons to take deontologically permissible means to prevent such extinction: to conduct research on risks and risk-reduction, promote political arrangements with an eye to the very far future, donate their money towards $\mathrm{x}$-risk mitigation, and so on. Indeed, given the gravity of the possible effect, and the perfect or negative form of the duty, they seem to have reason to do this even if it will considerably constrain their resources for classical forms of caritas.

Or that is as far as our argument takes us. There are many considerations relevant to non-transitionary anthropogenic extinction that I have not yet addressed. For instance, it would be interesting to explore the implications of Christian love for our question; to consider the relevance of other Christian virtues - such as temperance, diligence, or patience; or to integrate the assumption that in some form or other we will always live on, or that in this sense we cannot really die out. ${ }^{88}$ That is beyond the scope of this paper. It would also be interesting to consider the implications of my arguments for issues beyond my core question. Take risks of natural extinction. If we ought to ensure the preservation of the species, we must generally guard ourselves also against asteroid hits. It would presumably be a form of superbia to presume that no such event could erase us. And to let it happen would mean to let creation's most valuable part be destroyed. Allowing natural extinction might not be as grave as actively extinguishing ourselves. But it still seems a large-scale moral failure. Another, and more intricate question, concerns the issue of non-human higher intelligence. Suppose we turned into a nun-human AI and left mankind behind. Would we then miss our end (in the non-preservation of the species), or would we precisely fulfil it (in the perfection of our ingenuity)? Would it be a form of superbia to thus intervene in the nature of species, or would that belong to our natural proportionate capacities? And would the most valuable aspect of the universe be lost, or would the cosmos become more valuable if inhabited

88 I thank Dominic Roser for mentioning this thought to me. 
by a more perfect form of reason? ${ }^{89}$ Again, these are questions for another occasion.

There is also the question whether similar arguments emerge on other religious or non-religious worldviews. They arguably do. Our three thoughts - the special status of humanity, an ideal of humility, and a perfectionist obligation to develop our nature - emerge from a very general view of ourselves: from the sense that our nature is singularly valuable, and that this value obliges us to develop our potential and not decide on our existence as we please. This view need not be grounded in the Christian God. Indeed, it need not be grounded in any God. We arguably find such a view of humanity, and forms of our three thoughts, in as secular a thinker as Kant. Kant evidently thought that we are especially valuable: "the human being, and in general every rational being, exists as end in itself, not merely as means to the discretionary use of this or that will." 90 Indeed for Kant, among all material creatures, only human beings are ends in themselves. Thus the physical cosmos would be devoid of intrinsic value altogether if we drove ourselves extinct. Accordingly, the fact that we are ends in ourselves sets limits to what we may do: "If [man] destroys himself in order to flee from a burdensome condition he makes use of a person [i.e., his own person] merely as a means." 91 More generally, our value implies we must not discard ourselves, or risk our demise, without very good reason. Driving ourselves extinct, due to a failure of good care, would manifest an overstepping of our discretion - a lack of humility not so much vis-à-vis God, but vis-à-vis our own dignity. Indeed, Kant thinks we must positively develop our potential: "Man has a duty to himself to cultivate [...] his natural powers [...], not to leave idle and, as it were, rusting away [his] natural predispositions and capacities." 92 Thus there is a perfectionist, almost natural-law-like strand in Kant's thought. In failing to develop our potential, flourish, or fulfil our nature, we would flout a duty against ourselves. So the general gist of our arguments is not parochial to Christians. It is at bottom simply our dichotomous nature - immensely valuable yet fallen and fragile - which implies we should be exceedingly careful with ourselves. Christians, and everyone with a similar view of mankind, and of our value

89 I thank Mara-Daria Cojocaru and Carin Ism for mentioning these questions to me. For a generally positive Christian stance on enhancement, see e.g. Keenan, "Catholic Christianity."

90 AA IV:428 (Groundwork, 45; emphasis removed).

91 AA IV:429 (Groundwork, 47).

92 AA VI:444 (Metaphysics, 239). 
and limitations and obligations, should agree with effective altruists that reducing extinction risks is extremely important. ${ }^{93}$

\section{References}

Aquinas, Thomas. Disputed Questions on Virtue [DQV]. Translated by Jeffrey Hause and Claudia Eisen Murphy. Indianapolis: Hackett, 2010.

- Summa Theologica [ST], second and revised edition. Translated by Fathers of the English Dominican Province. London: Burns Oates \& Washbourne, 1920.

- Summa Contra Gentiles [SCG]. Edited by Joseph Kenny O.P. Translated by Anton C. Pegis, James F. Anderson, Vernon J. Bourke, Charles J. O’Neil. New York: Hanover House, 1955-57.

—. Scriptum super Sententiis [SSS]. Accessed 17 September 2019. http://www.corpusthomisticum.org/iopera.html.

Augustine. The City of God Books XIII and XIV [De Civ. Dei]. Edited and Translated by Peter G. Walsh. Liverpool: Liverpool University Press, 2017.

Bagemihl, Bruce. Biological Exuberance: Animal Homosexuality and Natural Diversity. New York: St Martin's Press, 1999.

Bostrom, Nick, and Milan M. Ćirković, editors. Global Catastrophic Risks. Oxford: Oxford University Press, 2008.

Bostrom, Nick. "Astronomical Waste: The Opportunity Cost of Delayed Technological Development.” Utilitas 15, no. 3 (2003): 308-314.

. "Existential Risk Prevention as Global Priority." Global Policy 4, no. 1 (2003): 15-31.

Beckstead, Nick. "On the Overwhelming Importance of Shaping the Far Future.” PhD Dissertation, Rutgers, 2013.

Bucknam, Mark, and Robert Gold. "Asteroid Threat? The Problem of Planetary Defence." Survival 50, no. 5 (2008): 141-156.

Cave, Stephen, and Seán S. ÓhÉigeartaigh. "Bridging near- and long-term concerns about AI.” Nature Machine Intelligence 1 (2019): 5-6.

93 For helpful comments on earlier versions of this paper, I thank the participants of the workshop Religious Perspectives on Effective Altruism, the participants of the 5th Oxford Workshop on Global Priorities Research, as well as Hilary Greaves, Christoph Halbig, Samuel Hughes, Sebastian Muders, Philipp Schwind and Felix Timmermann, and especially Dominic Roser and Ludovico Conti. 
Denkenberger, David, and Joshua M. Pearce. Feeding Everyone No Matter What: Managing Food Security After Global Catastrophe. London: Elsevier, 2015.

Dietz, Alexander. "Effective Altruism and Collective Obligations." Utilitas 31, no. 1 (2019): 106-115.

Finnis, John. Natural Law and Natural Rights. Oxford: Oxford University Press, 2011.

Fullam, Lisa. The Virtue of Humility: A Reconstruction Based in Thomas Aquinas. Ph.D. Dissertation, Harvard University, 2001.

Haldane, John, and Patrick Lee. "Aquinas on Human Ensoulment, Abortion and the Value of Life." Philosophy 78, no. 2 (2003): 255-278.

Hanson, Robin. "Catastrophe, social collapse, and human extinction."

In Global Catastrophic Risks, edited by Nick Bostrom and Milan M. Ćirković, 363-378. Oxford: Oxford University Press, 2008.

HM Treasury. "Stern Review on the Economics of Climate Change." Accessed 15 May 2019. https://webarchive.nationalarchives.gov.uk/u kgwa/20100407172811/https://www.hm-treasury.gov.uk/stern_review_r eport.htm.

Kant, Immanuel. The Metaphysics of Morals. Translated by Mary J. Gregor. Cambridge: Cambridge University Press, 1991.

Kant, Immanuel. Groundwork of the Metaphysics of Morals. Translated by Mary J. Gregor. Cambridge: Cambridge University Press, 1998.

Keenan, James F. "Roman Catholic Christianity, Embodiment and Relationality: Roman Catholic Concerns about Transhumanist Proposals.” In Transhumanism and the Body: The World Religions Speak, edited by Calvin Mercer and Derek F. Maher, 155-171. New York: Palgrave, 2014.

Linzey, Andrew. Christianity and the Rights of Animals. Eugene: Wipf and Stock Publishers, 2016.

Lisska, Anthony J. Aquinas's Theory of Natural Law: An Analytic Reconstruction. Oxford: Oxford University Press, 1998.

MacAskill, William. Doing Good Better: How Effective Altruism Can Help You Make a Difference. New York: Gotham Books, 2015.

Nussbaum, Martha C. Creating Capabilities: The Human Development Approach. Cambridge, MA: Belknap/Harvard University Press, 2011.

- "Non-Relative Virtues: An Aristotelian Approach." Midwest Studies in Philosophy 13, no, 1 (1987): 32-53.

Ord, Toby. The Precipice: Existential Risk and the Future of Humanity. London: Bloomsbury, 2020. 
Paley, William. The Principles of Moral and Political Philosophy. Cambridge: Cambridge University Press, 2014.

Pamlin, Dennis, and Stuart Armstrong. "Global Challenges: 12 Risks that threaten human civilisation.” Accessed 8 August 2019. https://static1.squ arespace.com/static/59dc930532601e9d148e3c25/t/59f1 1eebfe54ef5bd7 6cb38d/1508974382403/12-Risks-that-threaten-human-civilisation-GC F-Oxford-2015.pdf.

Parfit, Derek. Reasons and Persons. Oxford: Oxford University Press, 1984.

Pasnau, Robert. Thomas Aquinas and Human Nature. Cambridge: Cambridge University Press, 2002.

Pinker, Steven. Enlightenment Now: The Case for Reason, Science, Humanism, and Progress. New York: Penguin, 2018.

Richter, Daniel, Rainer Grün, Renaud Joannes-Boyau, Teresa E. Steele, Fethi Amani, Mathieu Rué, Paul Fernandes, Jean-Paul Raynal, Denis Geraads, Abdelouahed Ben-Ncer, Jean-Jacques Hublin, and Shannon P. McPherron. "The age of the hominin fossils from Jebel Irhoud, Morocco, and the origins of the Middle Stone Age." Nature 546 (2017): 293-296.

Rushby, Andrew J., Mark W. Claire, Hugh Osborn, and Andrew J. Watson. "Habitable Zone Lifetimes of Exoplanets around Main Sequence Stars." Astrobiology 13, no. 9 (2013): 833-849.

Sandberg, Anders, and Nick Bostrom. "Global Catastrophic Risks Survey." Future of Humanity Institute Technical Report. Accessed 15 May 2019. http://www.global-catastrophic-risks.com/docs/2008-1.pdf.

Tadie, Joseph Lawrence. Between Humilities: A Retrieval of Saint Thomas Aquinas on the Virtue of Humility. Ph.D. Dissertation, Boston College, 2006.

Todd, Benjamin. "Presenting the long-term value thesis." Accessed 15 May 2019. https://80000hours.org/articles/future-generations/.

United Nations, Department of Economic and Social Affairs, Population Division. "World Population Monitoring, 2001: population, environment and development." Accessed 15 May, 2019. https://www.un.org/en /development/desa/population/publications/pdf/environment/populatio n-monitoring.pdf.

Wiblin, Robert, and Howie Lempel. "What skills or experience are most needed within professional effective altruism in 2018? And which problems are most effective to work on? New survey of organisational leaders." Accessed 15 May 2019. https://80000hours.org/2018/10/20 18-talent-gaps-survey/. 
